\title{
Construction of Environmental Quality Evaluation Index System from the Perspective of Sustainable Development
}

\author{
Wang Qi \\ International Business School, Shanxi Normal University, Xi'an 710062, China \\ E-mail: 1239765205 @qq.com
}

\begin{abstract}
Key Words: Environmental quality, Comprehensive evaluation, Sustainable development , Analytic hierarchy process
\end{abstract}

\begin{abstract}
This paper analyzes the relationship between human development and environment from the perspective of "sustainable development". Based on literature review and following the general principles and methods of sustainable development, we establish a series of environmental indicators system, which is used to analyze the environmental situation in China during 2011-2013 with the analytic hierarchy process (AHP). Policies and recommendations are put forward for the sustainable development of human beings.
\end{abstract}

\section{Introduction}

With the climate warming, fossil energy depletion and environmental pollution increasing, the ocean-like pattern of economic growth, depending on natural conquering, encounters bottlenecks in the second half of the twentieth century. The concept of "sustainable development" was first proposed in the "Our Common Future" report published by the United Nations Commission on Environment and Development in 1987. It argues that people have the ability to develop sustainably and to ensure that development is not only to meet the needs of contemporary people, but also to meet the needs of the future generations. The path of cleaning up after pollution, developed countries have experienced, is no longer suitable for us, a large developing country. The problem of environmental pollution, as show by haze, has made our country rapidly transit to sustainable development.

\section{Literature Review}

The Joint Bureau of Statistics, the OEDC and the Committee on Environmental Issues have proposed a set of sustainable development indicators. OEDC first proposed a "stress-state-response" model that highlighted the causal relationship between environmental stress and environmental degradation; Since then, the United Nations Bureau of Statistics has modified it and incorporated social and economic indicators to form the FISD model; the Scientific Committee on Environmental Issues has suggested that environmental indicators must be linked to human activities, and then it presents a conceptual model of the interaction of human activities and the environment. The ESIs proposed by Samuel-Johnson and Daniel are used to measure the ability of a country or region to maintain a good environmental state for future generations, with the higher the EIS value, the stronger the ability of sustainable development. The "ecological footprint" indicator proposed by Mathis Walkernagel used the "land consumption / use" matrix to calculate the amount of land to be used to maintain resource consumption and waste absorption at a certain population and economies of scale. EMSI, proposed by Brown, estimates the energy of natural resources and human resources from a biological and physical point of view. He considered the carrying capacity of a system and output (ELR), where the lower the ELR, the better its sustainability.

China has also developed a large number of economists on the study of sustainable development. Guo Tianpei(2010) has a new understanding of the present situation and existing problems of environmental quality in China. He compared various environmental quality assessment methods 
and added the multivariate statistical method to the evaluation system. Chen Zhenzhen(1998) focused on the relationship between environmental protection and economy and population growth, and solved the problem of inconsistent environmental quality evaluation results due to the different levels of economic development. Wang Hesheng(1997) set up four criteria layers which are economic development, social progress, resource and environment support and sustainable development, and evaluated the sustainable development capability of developed areas in China. Zhang Shiqiu(1996) used a series of "stress-state-response" indicators to describe China's environment, with which to evaluate the sustainable development of China's evaluation.

These studies provide a solid theoretical and methodological basis for this paper, but there is a great deal of controversy about how to evaluate the sustainability of our country. Aiming at sustainable development, this paper tries to construct an environmental quality evaluation index system based on the "pressure - state - corresponding" between human and environment, which includes not only the status quo of environmental development but also the economic, social development and environmental protection management on the impact of environmental quality.

\section{The Design of Environmental Quality Evaluation Index System in China from the Perspective of Sustainable Development}

\subsection{Environmental STress Index}

Table1. Environmental stress index system

\begin{tabular}{|l|l|}
\hline \multirow{2}{*}{ Stress Index } & Energy consumption per unit of GDP \\
\cline { 2 - 2 } & Total sulfur dioxide emissions \\
\cline { 2 - 2 } & Cultivated area \\
\cline { 2 - 2 } & Total nitrogen oxides emissions \\
\hline
\end{tabular}

\subsection{Environmental Status Indicators}

Table2. Environmental status indicator system

\begin{tabular}{|c|c|}
\hline \multirow{6}{*}{ Status Indicator } & Forest reserves \\
\hline & $\begin{array}{c}\text { Above the level of urban air quality to more than two } \\
\text { standard ratio }\end{array}$ \\
\hline & Built green area rate \\
\hline & The total amount of sulfur dioxide emissions is reduced \\
\hline & Per capita park green area \\
\hline & $\begin{array}{l}\text { Unit of industrial added value to reduce water } \\
\end{array}$ \\
\hline
\end{tabular}

\subsection{Environmental Management Indicators}

Table3. Environmental quality management index system

\begin{tabular}{|c|c|}
\hline \multirow{4}{*}{ Management Index } & Harmless treatment rate of municipal solid waste \\
\cline { 2 - 3 } & Comprehensive utilization rate of industrial solid waste \\
\cline { 2 - 3 } & Centralized treatment rate of urban sewage \\
\cline { 2 - 3 } & $\begin{array}{c}\text { Industrial water reuse rate } \\
\text { Non-fossil energy accounted for the proportion of primary } \\
\text { energy consumption }\end{array}$ \\
\cline { 2 - 2 } & Environmental investment as the proportion of GDP \\
\hline
\end{tabular}

\section{Empirical Analysis}

4.1 Data Sources The data of environmental quality mainly quoted from "China Environmental Quality Report", "China Environment Statistical Yearbook"," 'Twelfth Five-Year' period of China's main indicators of environmental statistics" and "foreign environmental quality space planning", the economic development mainly from the "China Statistical Yearbook". 
Table4. Environmental quality index system target value

\begin{tabular}{|c|c|c|c|c|c|c|c|}
\hline & Index & Unit & $\begin{array}{l}\text { Target } \\
\text { Value }\end{array}$ & & Index & Unit & $\begin{array}{l}\text { Target } \\
\text { Value }\end{array}$ \\
\hline 1 & $\begin{array}{c}\text { Total nitrogen oxides } \\
\text { emissions }\end{array}$ & $\begin{array}{l}\text { Million } \\
\text { tons }\end{array}$ & 2046.3 & 9 & $\begin{array}{l}\text { Built green area } \\
\text { rate }\end{array}$ & $\%$ & $\geqq 35.6$ \\
\hline 2 & Cultivated area & $\begin{array}{l}\text { Billion } \\
\mathrm{mu}\end{array}$ & $\leqslant 18.18$ & 10 & $\begin{array}{l}\text { Harmless treatment } \\
\text { rate of municipal } \\
\text { solid waste }\end{array}$ & $\%$ & 90 \\
\hline 3 & Forest reserves & $\begin{array}{l}\text { Billion } \\
\text { cubic } \\
\text { meters }\end{array}$ & 143 & 11 & $\begin{array}{l}\text { Centralized } \\
\text { treatment rate of } \\
\text { urban sewage }\end{array}$ & $\%$ & $\geqq 85$ \\
\hline 4 & $\begin{array}{l}\text { Industrial water reuse } \\
\text { rate }\end{array}$ & $\%$ & $\geqq 80$ & 12 & $\begin{array}{l}\text { Per capita park } \\
\text { green area }\end{array}$ & $\begin{array}{l}\text { Square } \\
\text { meters }\end{array}$ & 10.3 \\
\hline 5 & $\begin{array}{l}\text { Energy consumption } \\
\text { per unit of GDP }\end{array}$ & $\begin{array}{l}\text { Tons/ } \\
\text { million } \\
\text { yuan }\end{array}$ & 0.702 & 13 & $\begin{array}{l}\text { Above the level of } \\
\text { urban air quality to } \\
\text { more than two } \\
\text { standard ratio }\end{array}$ & $\%$ & $\geqq 80$ \\
\hline 6 & $\begin{array}{c}\text { Comprehensive } \\
\text { utilization rate of } \\
\text { industrial solid waste }\end{array}$ & $\%$ & $>72$ & 14 & $\begin{array}{l}\text { Sulfur dioxide } \\
\text { emissions reduction } \\
\text { ratio }\end{array}$ & $\%$ & 8 \\
\hline 7 & $\begin{array}{l}\text { Unit of industrial added } \\
\text { value to reduce water } \\
\text { consumption }\end{array}$ & $\%$ & 0.53 & 15 & $\begin{array}{l}\text { Environmental } \\
\text { investment as the } \\
\text { proportion of GDP }\end{array}$ & $\%$ & 3 \\
\hline 8 & $\begin{array}{l}\text { Non-fossil energy } \\
\text { accounted for the } \\
\text { proportion of primary } \\
\text { energy consumption }\end{array}$ & $\%$ & 11.4 & 16 & $\begin{array}{c}\text { Total sulfur dioxide } \\
\text { emissions }\end{array}$ & $\begin{array}{l}\text { Million } \\
\text { tons }\end{array}$ & 2086.4 \\
\hline
\end{tabular}

\subsection{Overall Merit}

\subsubsection{Determination of the Index Weight}

Table5. Index Weight of Environmental Quality Index System

\begin{tabular}{|c|c|c|c|c|}
\hline $\begin{array}{l}\text { First level } \\
\text { indicator }\end{array}$ & $\begin{array}{c}\text { Second level } \\
\text { indicator }\end{array}$ & \multicolumn{2}{|r|}{ Third level indicator } & Weights \\
\hline \multirow{10}{*}{$\begin{array}{l}\text { Environmental } \\
\text { quality } \\
\text { indicators(A1) }\end{array}$} & \multirow{4}{*}{$\begin{array}{c}\text { Stress Index } \\
(0.1453) \\
\text { B1 }\end{array}$} & 1 & Energy consumption per unit of GDP (C1) & 0.0616 \\
\hline & & 2 & Total sulfur dioxide emissions(C2) & 0.0067 \\
\hline & & 3 & Cultivated area(C3) & 0.0092 \\
\hline & & 4 & Total nitrogen oxides emissions (C4) & 0.0678 \\
\hline & \multirow{5}{*}{$\begin{array}{r}\text { Status } \\
\text { indicator } \\
(0.4653) \\
\text { B2 }\end{array}$} & 5 & Forest reserves(C5) & 0.3049 \\
\hline & & 6 & $\begin{array}{l}\text { Above the level of urban air quality to more than two } \\
\text { standard (C6) }\end{array}$ & 0.0417 \\
\hline & & 7 & Built green area rate $(\mathrm{C} 7)$ & 0.0128 \\
\hline & & 8 & Sulfur dioxide emissions reduction ratio(C8) & 0.0797 \\
\hline & & 9 & Per capita park green area(C9) & 0.0091 \\
\hline & & 10 & $\begin{array}{l}\text { Unit of industrial added value to reduce water } \\
\text { consumption(10) }\end{array}$ & 0.0171 \\
\hline
\end{tabular}




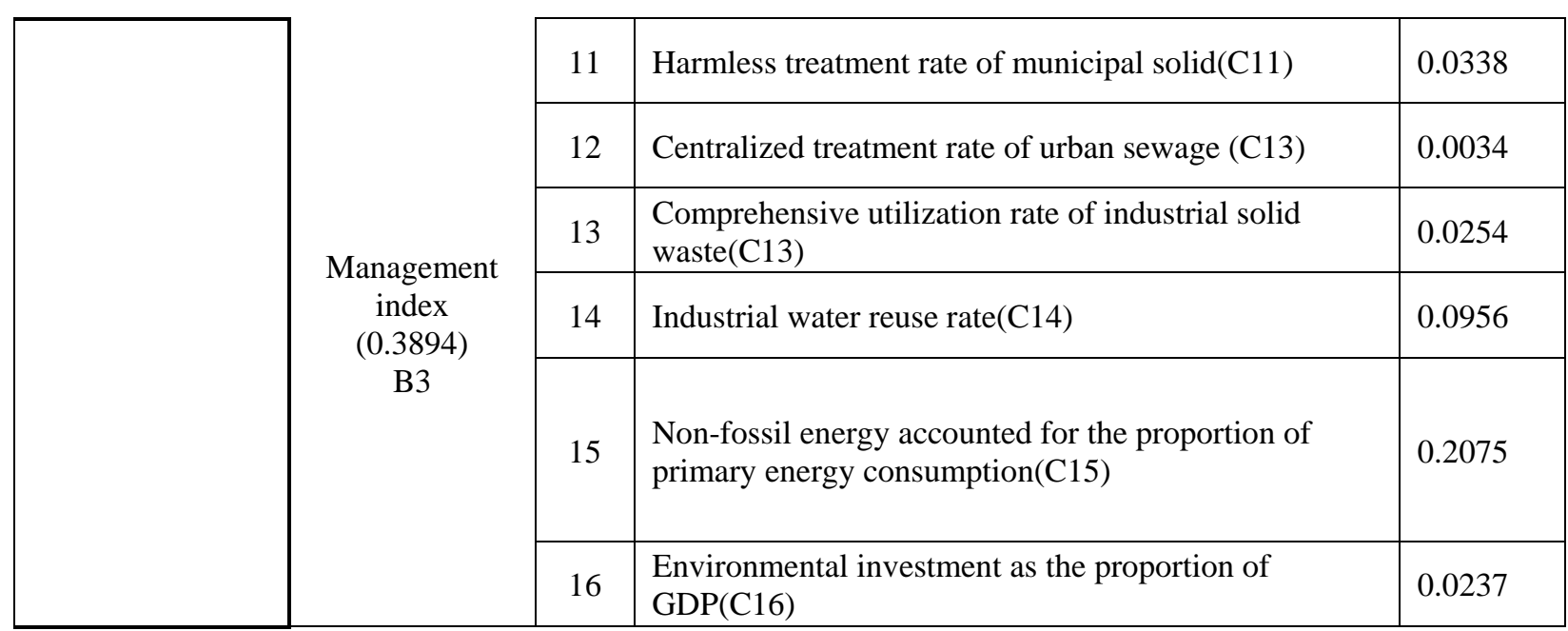

4.2.2 Non-dimensional Processing of Data. Due to the different dimensions of each index in the environmental quality index system, weight cannot be weighted directly, so we must deal with the data without dimension. The actual value of each index is divided by the evaluation standard value, and then the evaluation index of each index is obtained, the evaluation index of each index is weighted average, and the comprehensive evaluation value is obtained.

Table6. Comprehensive Evaluation of Environmental Indicators Quality in China from 2011 to2013

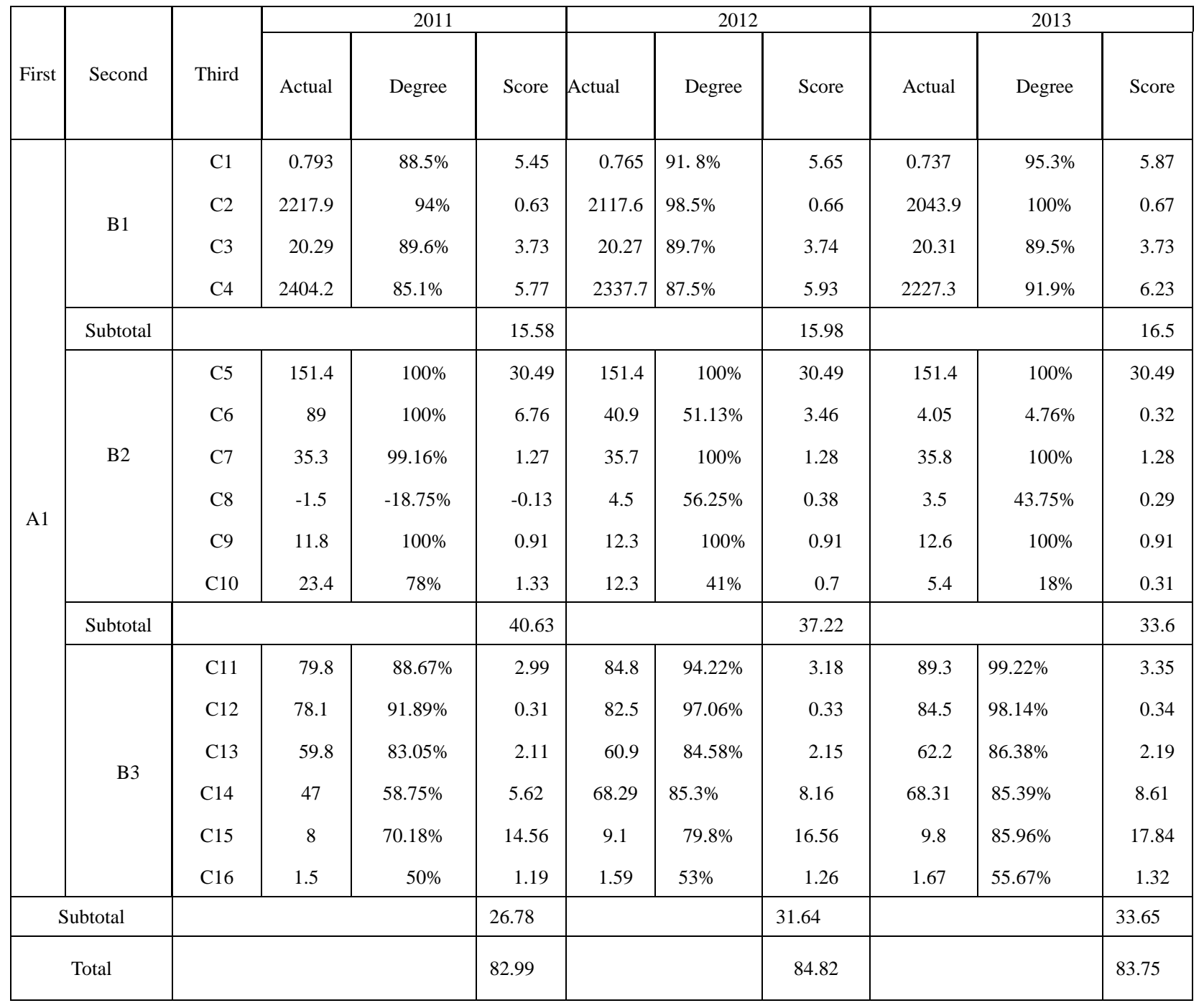




\section{Policies and Recommendations}

5.1 Continue to Limit the Total Emissions of Major Pollutants The government should promote the supply side reform vigorously and eliminate backward production capacity, and improve the key industry environmental access and emission standards which will force enterprises to upgrade the industrial structure and ultimately achieve energy-saving emission. The law should strictly prohibit those who consume high energy and serious pollution of the development of enterprises, and vigorously develop the quality, efficiency and resource-saving industries. All regions should improve the monitoring and assessment system and encourage the factory to control the total discharge. Chemical industry should control the total amount of chemical oxygen demand and ammonia emissions.

5.2 Strengthen Environmental Law Enforcement Supervision Our country should pay close attention to the development of relevant laws and establish a law enforcement responsibility system, which should provide a more complete and effective legal protection for environmental protection. EPA should strengthen the daily supervision and enforcement of environmental protection. And they should continue to carry out the special action to regulate the illegal sewage enterprises and to protect the masses of health and environmental. The government should implement the system of extended producer responsibility, deepen the enterprise environmental supervisor system, establish the environmental protection reporting system, and strengthen the social supervision of environmental protection.

5.3 Deepen the Comprehensive Prevention and Control of Pollution in Key Areas In order to effectively prevent environmental risks of drinking water sources and ensure that people drink clean water, our government must strengthen the protection of drinking water sources, carrying out water quality analysis regularly, implementing the water environmental remediation, restoration and construction, and improving the water quality compliance rate. The regional environmental quality supervision bureau should also actively carry out groundwater pollution investigation, risk assessment and repair demonstration, and should continue to promote the key river basin water pollution prevention. China's environmental air quality standards should increase the air pollutant monitoring indicators, improve the environmental quality assessment methods and the mechanism for joint prevention and control of air pollution in key areas. The provinces and cities should increase the municipal solid waste treatment and industrial solid waste comprehensive treatment. For the re-development and utilization of contaminated sites, they should carry out environmental assessment and harmless management; carry out comprehensive urban environment comprehensive renovation and environmental protection model city.

5.4 Reduce Living Pollution, From the Side to Start In recent years, the problem of haze is mainly due to industrial waste gas, automobile exhaust and other emissions, which seriously affected our health. PM2.5 masks have made our outstretched items, but these cannot really solve the root cause problem. We should start from the side, such as: going out as far as possible by bus, walking or cycling; strengthening the recycling of water, disposing the sewage at prescribed place; classifying the household waste; reducing the use of coal and using some low-consumption new energy; reducing the use of disposable cutlery and so on. Finally, we must strengthen the quality of the people and raising the public awareness of environmental protection. We need to protect the Earth because it is our home. The protection of the environment requires our common efforts.

\section{References}

[1] Chen Zhenzhen, Sustainable Development and Evaluation Index System , China Economic Studies, vol. (06), pp.37-42, 1998.

[2] Zhang Shiqiu, A Preliminary Study on the Index System of Sustainable Development, The Journal of World Economy, vol. (03) , pp.8-9, 1996.

[3] H Opschoor, The green economy: Environment, sustainable development and the politics of the future, Ecological Economics, vol12, pp. 256-256, 1995. 